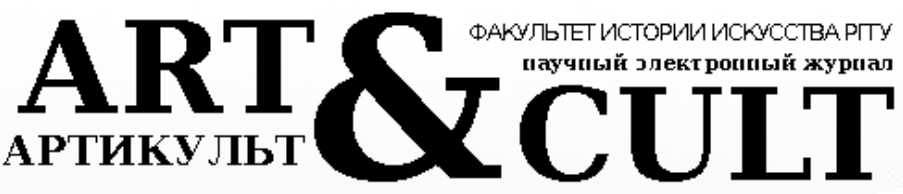

DOI: 10.28995/2227-6165-2018-3-92-104

\title{
С.Ю. Манухина
}

кандидат психологических наук, доцент кафедры Общей психологии Института общественных наук РАНХиГС при Президенте Российской Федерации alday@inbox.ru

\section{ОСОБЕННОСТИ ЦЕННОСТНО-СМЫСЛОВОЙ, КОГНИТИВНОЙ И ЭМОЦИОНАЛЬНОЙ СФЕР У ДЕВУШЕК ПОДРОСТКОВОГО ВОЗРАСТА, ПОДВЕРГШИХСЯ НАСИЛИЮ СО СТОРОНЫ СВЕРСТНИКОВ}

Проблема подросткового насилия - злободневная и сложная тема. Очень много фактов насилия не фиксируется в официальных источниках. Часто самим подросткам бывает сложно сразу понять, что с ними произошло, куда и к кому идти за поддержкой. Многие замалчивают свои проблемы. Примечательно, что проявление насилия встречается не только в криминальных подростковых коллективах, но и во вполне благопристойных на первый взгляд юношеских обществах. Нарушение физических границ может быть существенной травмой для неокрепшей психики подростка, не привыкшему к подобным действиям. В нашей статье мы приводим данные исследования особенностей ценностно-смысловой, когнитивной и эмоциональной сфер у девушек подросткового возраста, подвергшихся насилию со стороны сверстников.

Ключевъе слова: насилие, подростки, девушки, сверстники, самоэффективность, когнитивная сфера, эмоциональная сфера, эмоции, ценности, ценностносмысловая сфера, травма, психологическое консультирование
The problem of adolescent violence is a complex and topical issue. A lot of violence facts are not recorded by official sources. Teenagers often do not understand what happened of them, whom they can ask to help, where they can go. Many adolescents ignore their problems. It is interesting that the teenage violence is not only in criminal teenage collectives, but also in quite respectable communities. Destruction of physical boundaries can be a deep trauma to the immature mentality of a teenager, who is not used to such actions. In our article, we present the research's data of the value sphere, the cognitive and emotional spheres among adolescent girls who were exposed to violence by the peers.

Keywords: adolescent violence, teenage violence, teenage, violence, cognitive indicators, values, emotions, self-efficacy, psychological trauma, peers, violence behavior, psychological counseling, recommendations

В период с 1995 по 2005 гг. участилось количество криминальных действий со стороны групп подросткового возраста. Действия таких подростков поражают своей жестокостью и количеством насилия. Причем насилие ими применяется не только по отношению к окружающему миру, но и к своим «собратьям». Явный переломный момент наметился в 2008 г., когда количество преступлений, совершаемых подростками, пошло на снижение. К 2015 году по данным Росстата количество преступлений снизилось в три раза [Официальная статистика Федеральной службы государственной статистики, 2018]. Но это только официальная статистика зафиксированных преступлений, дошедших до суда. Опыт работы с подростками, с разными жизненными ситуациями показывает, что количество «замалчивыемых» нарушений осталось на том же уровне. В том числе, связанных с переходом норм физических отношений.

Проявление насилия в подростковой среде может носить как осознанный характер (наказать провинившегося, чтобы другим было не повадно), так и неосознанный или частично осознанный (например, насилие в пьяном виде). Примечательно, что проявление насилия встречается не только в криминальных подростковых коллективах, но и во вполне благопристойных на первый взгляд 


\section{S.Yu. Manukhina The research of the values, the cognitive and emotional indicators of adolesent girls who were exposed to violence by the peers}

юношеских обществах: на дискотеках, тусовках, сейшенах и даже обычных днях рождениях - там, где подростки остаются без «всевидящего ока» взрослого. Многими школьными психологами отмечается, что количество насильственных действий именно в подростковой среде среди сверстников встречается намного чаще, чем сиблинговое насилие [Тухарев, 2001; Манухина и др., 2015; Здоровье и безопасные отношения..., 2016]. По их же мнению двигателем подобных действий в значительной степени является сам социум, «разрешающий» такое поведение: фильмы, журналы, возможность обсуждать и говорить на подобные темы, не опасаясь порицаний со стороны окружающих. Результатом является повышенная безответственность к вопросам жизни другого, его личным и физическим границам. Многие подростки не умеют остановить конфликтную ситуацию, а при возникновении таковой начинают вести себя еще более провоцирующе и вызывающе, тем самым усугубляя ситуацию. Впоследствии большинство из них свое поведение характеризуют как «вынужденное», «нежелательное», сожалеют о происшедшем, но признают, что в тот момент не видели другого выхода. Практически все из них испытывают переживания и демонстрируют стрессовые реакции. Особую группу составляют девушки из благополучных семей, подвергшиеся неожиданному насилию со стороны сверстников. Общество, которому они доверяли (возможно учились вместе или дружили много лет), вдруг повернулось к ним другой стороной. Нарушение физических границ может быть существенной травмой для неокрепшей психики подростка, не привыкшего к подобным действиям. Все то, что сопутствует подобным событиям, оказывает существенное влияние на сферу ценностностных представлений девушек, их эмоциональную лабильность, саму структуру личности, находя свое отражение практически во всех аспектах их последующей жизни [Robinson, Smith, Segal, 2018; Gomez-Baya1, Mendoza, Paino, 2016; Kumari, Sandhya, 2015]. Подвергается испытанию само представление их о жизни, о себе, о возможности и дальнейших путях существования. Вот почему так важно исследовать те закономерности психических изменений, которые происходят у девушек-подростков, переживших травматический опыт насильственного поведения со стороны сверстников.

Таким образом, объектом нашего исследования стала ценностно-смысловая, когнитивная и эмоциональная сферы девушек подросткового возраста, подвергшихся насилию со стороны своих сверстников и имеющих признаки посттравматического стресса.

В качестве предмета исследования выступили:

- показатели ценностно-смысловой сферы (перечень ценностно-смысловых представлений);

- когнитивные показатели: вера в роль усилий и вера в роль способностей, общая и школьная самоэффективность;

- эмоциональные показатели: депрессия как состояние и как черта; школьная, самооценочная и межличностная тревожности.

Основной целью нашей работы стало определение отличительных особенностей показателей ценностно-смысловой, когнитивной и эмоциональной сфер у девушек, подвергшихся насилию со стороны своих сверстников. Для достижения этой цели нами были поставлены следующие задачи исследования:

- Провести диагностику ценностно-смысловой, когнитивной и эмоциональной сфер у девушек, подвергшихся насилию их сверстниками, и девушек того же возраста, не имеющих подобного опыта.

- Выявить среди девушек, подвергшихся насилию со стороны сверстников, тех, у кого наблюдаются признаки посттравматического стресса.

- Провести сравнительный анализ показателей ценностно-смысловой, когнитивной и эмоциональной сфер между группами девушек, подвергшихся насилию со стороны своих сверстников, и девушек, не имеющих подобного опыта.

В соответствии с целями и задачами исследования нами была выдвинута основная гипотеза исследования:

У девушек с проявлением синдрома посттравматического стресса, подвергшихся насильственным действиям со стороны сверстников, кроме изменений в эмоциональной сфере выражены нарушения в когнитивной и ценностно-смысловой сферах. 
С.Ю. Манухина Исследование особенностей ценностно-смысловой, когнитивной и эмоциональной сфер у девушек подросткового возраста, подвергшихся насилию...

Так же нами был обозначен ряд частных гипотез:

1. У девушек, имевших опыт насилия со стороны сверстников, представления о самоэффективности в деятельности значимо занижены в сравнении с девушками, подобного опыта не имевшими.

2. Оказанные действия насилия отложили свой отпечаток на восприятие ими своих интеллектуальных способностей: как вера в роль усилий, так и вера в роль способностей у них значительно ниже, чем у девушек, не подвергавшихся насилию.

3. Девушки, пережившие насилие со стороны сверстников, отличаются повышенным уровнем тревожности и проявлением депрессивных тенденций в поведении.

4. Структура ценностно-смысловых представлений у девушек, подвергшихся насилию, иная, чем у девушек, не имевших подобного опыта.

\section{Методическое обеспечение исследования.}

Репрезентативность выборки. Данное исследование состояло из двух этапов: 2001-2004 гг. и 2013 -2015 гг. На первом этапе исследований сбор эмпирических данных проводился в течение 3-х лет (с 2001 по 2004 годы). Непосредственно через этап диагностики ценностно-смысловой, когнитивной и эмоциональной сфер прошло 473 человека. Во втором периоде исследования (с 2013 по 2015 годы) диагностику прошли 438 подростка. В группу испытуемых вошли учащиеся как имеющие, так и не имеющие опыта насилия. Эта работа является своеобразным продолжением цикла предыдущих наших работ, посвященных изучению структуры когнитивных, мотивационных и ценностно-смысловых детерминант деятельности [Манухина, 2003; Godeeva, Manuchina, Shatalova, 2002]. В них была задействована та часть выборки, в которую вошли учащиеся, не подвергающиеся насилию. В настоящей же работе пристальное внимание уделялось учащимся, имеющим опыт насилия.

В итоге в само эмпирическое исследование на первом его этапе было включено 94 девушек, учащихся в 10-х классах из 6-ти общеобразовательных школ г. Москвы. Из них 42 подвергались насилию со стороны сверстников; 52 подобного опыта не имели.

На втором этапе исследований из общей массы выборки было отобрано 89 девушек, 48 из которых подверглись насилию со стороны сверстников и 41 подобного опыта не имели.

Средний возраст испытуемых составил 16 лет.

Наличие насилия устанавливалось несколькими путями:

- при упоминании испытуемым о подобном событии в анкете и последующей беседе с психологом;

- о насилии в анкете упомянуто не было, однако, некоторые аспекты поведения учащегося насторожили педагогов, родителей и/ или психолога, что послужило причиной для более пристального наблюдения за подростком с последующей психологической работой с ним.

Присутствие посттравматических стрессовых расстройств у девушек, подвергшихся сексуальному насилию со стороны сверстников, диагностировалось качественным образом во время психологических сессий при работе с ними. При диагностике учитывались критерии посстравматического стрессового расстройства согласно классификации МКБ-10 [МКБ-10..., 1994].

Все девушки, вошедшие в контрольные группы (и на первом, и на втором этапах исследования), насилию не подвергались, действия, производимые другими подростками как насильственные, не трактовали, были членами полных семей, видимых показателей посттравматического стресса не демонстрировали.

Методический инструментарий. Методики, подобранные в целях нашего эмпирического исследования, отвечают требованиям, предъявляемым к психодиагностическому аппарату. При их выборе учитывались как литературные данные об их валидности, надежности и дифференцированности, так, и в случае давности этих данных и/ или их сомнительности, проводилось их дополнительное исследование. 


\section{S.Yu. Manukhina The research of the values, the cognitive and emotional indicators}

of adolesent girls who were exposed to violence by the peers

Таким образом, в эмпирическом исследовании нами применялись следующие методики:

- Опросник ценностных предпочтений Шварца. Авторами методики являются Ш. Шварц и В. Билски [Шварцер, Ерусалем, Ромек, 1996, с. 47-58]. Русскоязычная версия предложена О.А. Тихмондрицкой и Е.М. Дубовской [Тихмандрцикая, Дубровская, 1999, с. 80-90]. Опросник был построен на основе теории динамических отношений ценностей немецких психологов Ш. Шварца и В. Билски. Главной задачей опросника является выявление ценностных представлений, наиболее значимых для исследуемой группы индивидов;

- Опросник представления об усилиях и способностях. Авторами методики являются Т.Д. Литтл и Б. Ваннер [Little, Wanner, 1997], Йельский университет (США) и Институт развития и образования человека им. Макса Планка (Берлин, Германия). Русскоязычная версия предложена Т.О. Гордеевой [Литтл, Ваннер, Гордеева, 1998]. Теоретической основой опросника является целевой подход к мотивации, разработанный К. Двек [Dweck, 1996]. В результате обработки данных определяется, как ребенок воспринимает свои способности - с точки зрения прибыльной (способности изменяемы, поддаются улучшению) или данностной (способности фиксированы) теории способностей, на основании чего можно сделать предсказание относительно адаптивного или неадаптивного (беспомощного) характера мотивационных процессов;

- Шкала общей самоэффективности. Авторы методики - Р. Шварцер и М. Ерусалем. Русская версия предложена В. Ромеком [Шварцер, Ерусалем, Ромек, 1996]. Шкала была разработана на основе социально-когнитивной теории А. Бандуры, одним из центральных компонентов которой является понятие «самоэффективности». Однако авторы шкалы посчитали оправданным создание вопросника, измеряющего не специфическую, а общую самоэффективность.

Для проверки внутренней надежности теста был посчитан коэффициент $\alpha$ Кронбаха: $\alpha=0.847$ - что говорит о высокой согласованности по критерию корреляции пунктов со шкалой. Кроме того, был проведен факторный анализ, в результате которого оказалось, что имеет место только один ярко выраженный фактор, что подтверждает высокую степень однородности теста.

- Шкала школьной самоэффективности. Авторами шкалы являются Т. Литтл и Б. Ваннер [Little, Wanner, 1997]. Русскоязычная версия предложена Т.О. Гордеевой [Литтл, Ваннер, Гордеева, 1998]. Теоретической основой опросника является социально-когнитивная теория А. Бандуры и теория воспринимаемого контроля Э. Скиннер. Данная шкала направлена на измерение уровня самоэффективности в ситуации школьной деятельности. На основе полученных результатов можно сделать вывод о степени владения субъектом различными средствами, способствующими достижению успеха в конкретной ситуации школьной деятельности.

Данная шкала предлагается Т. Литтлом и Б. Ваннером как одна из шкал мультимедийного инструментария, предъявляемого в форме опросника, направленного на диагностику когнитивных компонентов мотивации достижения и, в частности, ощущения контролируемости действий детьми школьного возраста (Multi-CAM).

- Шкала личностной тревожности Кондаш-Прихожан была предложена О. Кондашем (1983). Автором русскоязычной версии является А.М. Прихожан [Прихожан, 200о]. В последние несколько лет методика подвергалась нескольким модификациям. В настоящий момент она состоит из четырех субшкал (далее - шкал) - школьной, самооценочной, межличностной и магической тревожности. В целях нашего исследования испытуемым предлагался вариант опросника, в который входили только три первые шкалы. Каждая шкала включала в себя десять жизненных ситуаций. Испытуемые должны были оценить по 5-ти балльной шкале степень тревоги, беспокойства или страха, которые могут быть вызваны каждой из ситуаций. В связи с исследовательскими целями нашей работы перевод в стены не осуществлялся.

- Методика оценки депрессии как состояния и как личностной черты Ч.Д. Спилбергера. Данная методика была разработана Ч.Д. Спилбергером в рамках подхода, дифференцирующего депрессию как состояние и как черту. Русскоязычный вариант методики был предложен Ю.Л. Ханиным [Карелин, 2007]. Методика состоит из двух независимых шкал: оценка депрессии как текущего состояния и оценка депрессии как личностной черты. Каждая из шкал содержит в себе 
С.Ю. Манухина Исследование особенностей ценностно-смысловой, когнитивной и эмочиональной сфер у девушек подросткового возраста, подвергшихся насилию... десять утверждений, которые необходимо оценить по 4-х балльной шкале. Каждая из шкал включает в себя два фактора: проявление депрессивных переживаний, подавленного настроения (Dysthymia) и проявление переживания бодрости, веселья, приподнятого настроения (Euthymia). Таким образом, при обработке данных вопросы, которые входят в фактор «дистимия» считаются как прямые, а входящие в фактор «эйтимия» - как обратные. Диапазон суммарных баллов может варьироваться от 10 до 40.

- Кроме того, дополнительно нами учитывался показатель школьной успеваемости испытуемых.

- Анкета. Настоящая анкета была составлена нами в целях определения адаптации учащихся к учебному процессу, диагностики особенностей эмоционального климата учебного коллектива, а также определения проблемных сфер учеников.

Каждому учащемуся методики предъявлялись в заранее подготовленной «книжечке». При этом каждому из испытуемых раздавались бланки для занесения ответов.

Методы анализа и обработки данных. Для проведения сравнительного исследования значений измеряемых показателей между группами девушек, подвергшимися насилию со стороны сверстников (ОПН - объект подросткового насилия), и девушек, не имеющих подобного опыта (норма), использовался непараметрический критерий Манна-Уитни.

Кроме того, для определения надежности-согласованности пунктов ряда применяемых нами опросников, был подсчитан коэффициент внутренней надежности а (альфа) Кронбаха.

Для обработки данных использовались программа SPSS версий 10.0 и 22.0 for Windows.

\section{Результаты исследования.}

Проведение сравнительного анализа показателей когнитивной, ценностной и эмоциональной сфер в группах девушек, не подвергающихся насилию, и девушек, имеющих подобный опыт за два периода исследования, позволил выявить у последних следующий ряд закономерных особенностей (табл. 1).

\begin{tabular}{|c|c|c|c|c|c|}
\hline \multirow{2}{*}{$\begin{array}{l}\text { Периоды } \\
\text { исследован } \\
\text { ий }\end{array}$} & \multirow{2}{*}{$\begin{array}{l}\text { Статисти-ческие } \\
\text { обозначения }\end{array}$} & \multicolumn{4}{|c|}{ Показатели когнитивной сферы } \\
\hline & & $\begin{array}{l}\text { Общая } \\
\text { самоэффе } \\
\text { к- } \\
\text { тивность }\end{array}$ & $\begin{array}{l}\text { Школьная } \\
\text { самоэффек } \\
\text {-тивность }\end{array}$ & $\begin{array}{l}\text { Вера в } \\
\text { роль } \\
\text { усилий }\end{array}$ & $\begin{array}{l}\text { Вера в роль } \\
\text { способ- } \\
\text { ностей }\end{array}$ \\
\hline \multirow{3}{*}{$\begin{array}{lr}\text { I } & \text { период } \\
\text { исследовани } \\
\text { я } 2001-2004 \\
\text { гг. }\end{array}$} & Mean норма (1) & 29,0 & 21,8 & 20,1 & 8,7 \\
\hline & $\begin{array}{l}\text { Mean } \\
\text { OПH (1) }\end{array}$ & 27,4 & 21,6 & 19,6 & 7,1 \\
\hline & \begin{tabular}{|l}
$\begin{array}{l}\text { Asymp. Sig. (2- } \\
\text { tailed) }\end{array}$ \\
\end{tabular} & $\begin{array}{l}, 050 \\
(p \leq 0,05)\end{array}$ & $\begin{array}{l}, 411 \\
(p>0,05)\end{array}$ & $\begin{array}{l}, 669 \\
(p>0,05)\end{array}$ & $\begin{array}{l}, 033 \\
(p \leq 0,05)\end{array}$ \\
\hline \multirow{3}{*}{$\begin{array}{lr}\text { II } & \text { период } \\
\text { исследовани } \\
\text { я } \\
2016 \text { гг. }\end{array}$} & Mean норма (2) & 28,9 & 21,9 & 20,3 & 8,9 \\
\hline & $\begin{array}{l}\text { Mean } \\
\text { ОПН (2) }\end{array}$ & 25,3 & 21,4 & 17,5 & 7,1 \\
\hline & $\begin{array}{ll}\begin{array}{l}\text { Asymp. Sig. } \\
\text { tailed) }\end{array} & \text { (2- } \\
\end{array}$ & $\begin{array}{l}, 007 \\
(p \leq 0,01)\end{array}$ & $\begin{array}{l}, 227 \\
(p>0,05)\end{array}$ & $\begin{array}{l}, 046 \\
(p \leq 0,05)\end{array}$ & $\begin{array}{l}, 016 \\
(p \leq 0,01)\end{array}$ \\
\hline $\begin{array}{l}\text { Между } \\
\text { группами } \\
\text { ОПН (1) и } \\
\text { ОПН (2) }\end{array}$ & $\begin{array}{l}\text { Asymp. Sig. (2- } \\
\text { tailed) }\end{array}$ & $\begin{array}{l}, 041 \\
(p \leq 0,05)\end{array}$ & $\begin{array}{l}, 522 \\
(p>0,05)\end{array}$ & $\begin{array}{l}, 049 \\
(p \leq 0,05)\end{array}$ & $\begin{array}{l}, 382 \\
(p>0,05)\end{array}$ \\
\hline
\end{tabular}

Таблица 1

Значение средних (mean) и значимость различий по показателям когнитивной сферы в группах девушек, подвергшихся сексуальному насилию (ОПН(1) и ОПН (2)), и девушек, не имеющих подобного опыта (норма (1) и норма (2)) за два периода исследований. 


\section{S.Yu. Manukhina The research of the values, the cognitive and emotional indicators}

of adolesent girls who were exposed to violence by the peers

Так, среди показателей когнитивной сферы было обнаружено, что уровень представления об общей самоэффективности в группе девушек, не подвергавшихся насилию, значимо выше, чем в группе девушек, имеющих подобный опыт $(\mathrm{p} \leq 0,05)$. Причем и в один, и в другой периоды исследования. Интересно, что во втором периоде исследования представление об общей самоэффективности в группе ОСП (2) значимо занижены по сравнению с девушками группы ОСП (1). Между показателями представления об школьной (частной) самоэффективности значимых отличий в группах обнаружено не было (р>0,05) (табл. 1). Подобные результаты указывают нам на то, что преимущественно страдает представление о самоэффективности в общем плане. Нарушается представление о том, как жить дальше, «насколько я самодетерминирован в этой жизни», «могу ли я вообще говорить о возможности ощущения своей эффективности». Когда же речь заходит о самоэффективности в конкретной области, например, в сфере школьной жизни (школьная самоэффективность) человек, перенесший насилие, может строить о себе представление как о вполне эффективном субъекте деятельности и даже игнорировать для себя то, что с ним произошло, переключаясь на конкретный вид деятельности. По-видимому, здесь играют значительную роль устойчивые паттерны поведения, выработанные еще в период до произошедшей травмы.

Что касается таких показателей когнитивной сферы как вера в роль усилий и вера в роль способностей, то оказалось, что значимых отличий показателя вера в роль усилий между исследуемыми группами не обнаружено в первый период исследования (p>0,05) и обнаружено во второй $((\mathrm{p} \leq 0,05)$, вера же в роль способностей в группе девушек, пострадавших от сексуального насилия, значимо ниже, чем в группе девушек, не имеющих подобного опыта (p $\leq 0,05)$ (табл. 1).

Результаты, полученные в первый период исследования, хорошо сочетаются с результатами, полученными при анализе показателей общей и частной (школьной) самоэффективности. Утрата веры в собственную самоэффективность, по-видимому, отражается и на представлении о своих способностях осуществлять ту или иную деятельность на должном уровне, соответствовать тем нормативам, которые он выработал для себя до травмирующего события. Однако сохранным осталась убежденность в эффективности приложения своих усилий к определенному виду действий («Через силу, применяя усилия, у меня может быть что-то и получится»). Этот момент созвучен с представлениями потерпевших о частной форме самоэффективности: в данной конкретно указанной области (желательно знакомой области) приложить усилия проще, безопаснее, чем надеяться на свои внутренние резервы (способности), которые подверглись серьезному испытанию и находятся в «болезненном состоянии».

Пародоксальным являются результаты во второй период исследования. Между группами ОСП (2) и норма (2) значимые различия наблюдаются по показателям веры в роль способностей и веры в роль усилия. Значимо более низкие показатели в группе ОСП (2) могут говорить о возникновении эмоциональной лабильности и потере желания бороться, достигать результата, безразличия к происходящему. Подобные симптомы описаны в работах М.Зелигмана, посвященных описанию такого состояния, как «выученная беспомощность» [Зелигман, 1997]. Обычно оно возникает после длительной целенаправленной травли. Однако, судя по результатам нашего исследования, оно может возникать после насильственных действий, совершенных относительно девушек, живущих в нормальных благополучных семьях и не имеющих до этого подобного опыта. Видимо, чем лучше экономическая и психологическая ситуация в стране и в окружении, тем острее воспринимаются подростками насильственные действия в отношении них.

В сфере ценностно-смысловых представлений в первый период исследований в группе девушек, подвергавшихся насилию, на первое место вышли такие ценностные представления как здоровье (физическое и психическое), ответственность, преданность, честность, умеренность, смирение. Последнее же место в списке заняли снисходительность, доброжелательность, самостоятельность, целеустремленность, уважение старших (рис. 1). В сравнении с этим, группа девушек, не имеющих опыта насилия, на первом месте продемонстрировала такие ценностные 


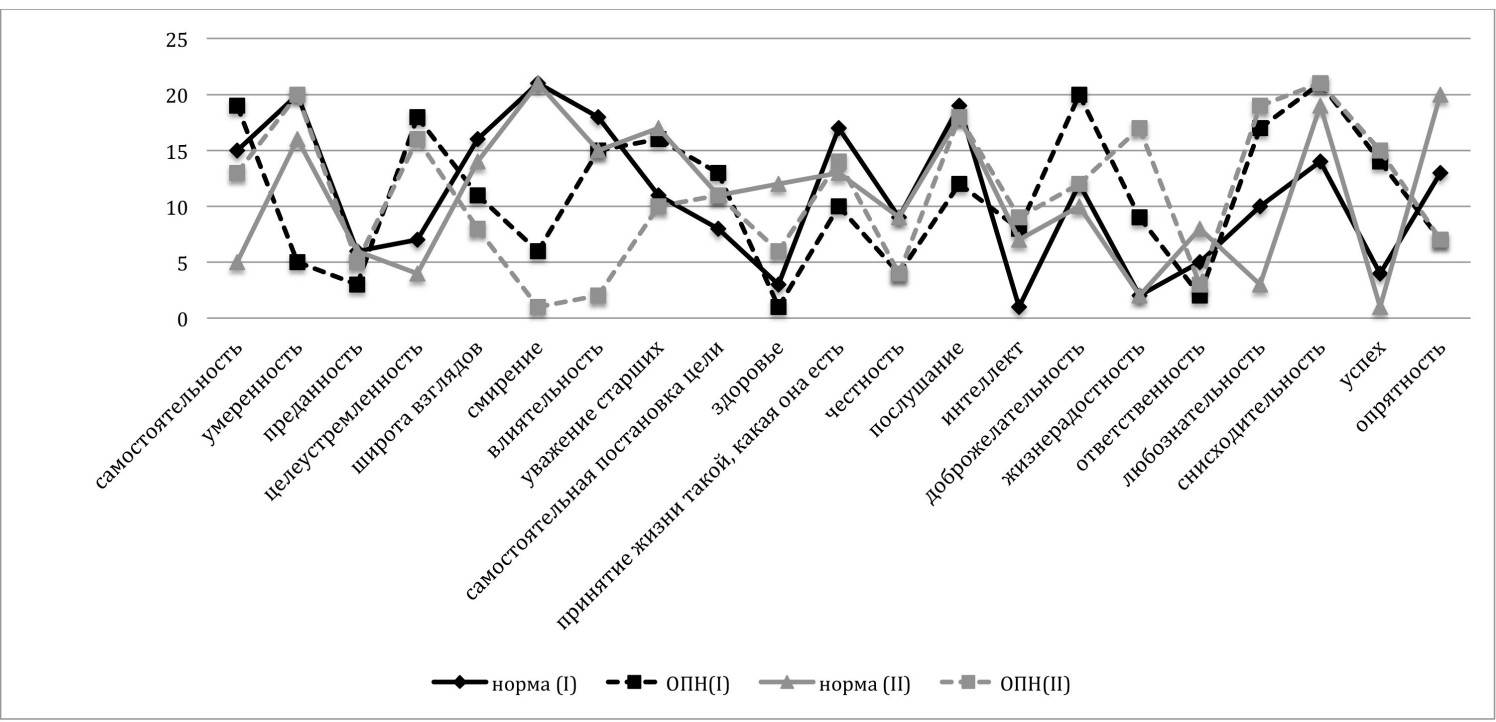

Рис. 1

Ценностные предпочтения в группах девушек, пострадавших от насилия (ОПН (1) и ОПН (2)), и девушек, подобного опыта не имеющих (норма(1) норма (2)) за два периода исследования.

представления как интеллект, жизнерадостность, здоровье, успех, ответственность. Последними же отмечаются смирение, умеренность, послушание, принятие жизни такой, какая она есть, снисходительность. В группе девушек ОПН (1) уходят на второй план ценность интеллектуальной деятельности и жизнерадостность. Таким образом, основываясь на особенностях сферы ценностносмысловых представлений, можно дать следующую портретную характеристику девушкам группы «норма». Они полны жизни, активны, где-то беззаботны, преимущественно направлены на достижение результата (особенно, что касается интеллектуальной жизни), успешное завершение своих начинаний. Они находятся в том душевном состоянии, когда жизнь кажется прекрасной во всех отношениях, когда невозможно представить, что все нельзя поменять в лучшую сторону, когда неприемлемо смирение и бездействие. Другая картина предстает перед нами при анализе особенностей сферы ценностно-смысловых представлений девушек группы ОПН (1). Их ранимость, принципиальность позиций граничит с агрессивностью и где-то даже озлобленностью по отношению к окружающим. Перестают цениться интеллектуальные достижения, эрудированность, любая активность - «движение вперед». Они как бы «застыли» в определенном состоянии, живут преимущественно сегодняшним днем, слабо заботясь о дне завтрашнем. Характерным является крайность их позиций - разделение мира на «белые и черные» стороны (честность, ответственность, преданность на первых позициях). При этом стремление к успеху, целеустремленность, направленность на достижение результата начинают занимать последние места в ряду их ценностных представлений.

Интересно, что перечень ценностно-смысловых представлений в группах девушек норма (1) и норма (2), не подвергающихся насилию, схож. Исключение составляют такие ценности, как здоровье, любознательность и самостоятельность (рис. 1). Ценность здоровья отходит на второй план. Современные девушки, подвергшиеся насилию (группа ОПН (2)), демонстрируют более парадоксальные результаты, чем подростки, принимавшие участие в исследовании десять лет назад. На первое место ими ставятся, с одной стороны, смирение, с другой стороны, влиятельность. А также честность, ответственность и преданность. При этом посушание, любознательность, жизнерадостность отодвигаются на второй план. Они жаждут власти и справедливости, но не готовы при этом слышать и слушать окружащих сверстников. Создается впечатление, что в сравнении с девушками группы ОПН (1), девушки группы ОПН (2) переживают и одновременно выжидают удобного случая, чтобы показать свою влиятельность. Возможно, даже через жестокость или силу. Интересно, что при этом, в сравнении с группой ОПН (1), они более ценят уважение к старшим. Это важный показатель для консультационной работы с ними. 


\section{S.Yu. Manukhina The research of the values, the cognitive and emotional indicators}

of adolesent girls who were exposed to violence by the peers

С точи зрения показателей эмоциональной сферы, группа девушек, подвергшихся насилию (и в первый, и во второй периоды исследования), продемонстрировала высокий уровень самооценочной и межличностной тревожности, а также оказалась склонной к проявлению депрессивных черт (депрессия-черта). Так, в сравнении с группой девушек, не имеющих опыта насилия, у группы девушек, подвергшихся насилию, значимо более выражен уровень показателей депрессии-черты $(\mathrm{p} \leq 0,05)$, самооценочной тревожности $(\mathrm{p} \leq 0,01)$ и межличностной тревожности $(\mathrm{p} \leq 0,05)$. Значимых различий по показателям депрессии-состояния и школьной тревожности в исследуемых группах обнаружено не было (р>0,05) (табл. 2). Интересно, что показатель самооценочной тревожности еще более значимо выражен у современных подростков, подвергшихся насилию со стороны сверстников (группа ОПН (2)), чем девушек, принимавших участие в исследовании десять дет назад (группа ОПН (1)).

\begin{tabular}{|c|c|c|c|c|c|c|}
\hline \multirow{2}{*}{$\begin{array}{l}\text { Периоды } \\
\text { исследован } \\
\text { ия }\end{array}$} & \multirow{2}{*}{\begin{tabular}{|l} 
Статисти- \\
ческие \\
обозначе- \\
ния
\end{tabular}} & \multicolumn{5}{|c|}{ Показатели эмоциональной сферы } \\
\hline & & $\begin{array}{l}\text { Депрессия } \\
\text {-черта }\end{array}$ & $\begin{array}{l}\text { Депрес- } \\
\text { сия- } \\
\text { состоя- } \\
\text { ние }\end{array}$ & $\begin{array}{l}\text { Тревож- } \\
\text { ность } \\
\text { самооце- } \\
\text { ночная }\end{array}$ & $\begin{array}{l}\text { Тревож- } \\
\text { ность } \\
\text { школь- } \\
\text { ная }\end{array}$ & $\begin{array}{l}\text { Тревож- } \\
\text { ность } \\
\text { межлич- } \\
\text { ностная }\end{array}$ \\
\hline \multirow{3}{*}{\begin{tabular}{|lr} 
I & период \\
исследовани \\
я \\
$2004 г г$. \\
$2001-$ \\
\end{tabular}} & $\begin{array}{l}\text { Mean норма } \\
\text { (1) }\end{array}$ & 18,0 & 19,9 & 13,6 & 10,3 & 14,3 \\
\hline & $\begin{array}{l}\text { Mean } \\
\text { OПН (1) }\end{array}$ & 19,2 & 19,4 & 15,0 & 10,3 & 16,6 \\
\hline & $\begin{array}{l}\text { Asymp. Sig. } \\
\text { (2-tailed) }\end{array}$ & $\begin{array}{l}, 023 \\
(p \leq 0,05)\end{array}$ & $\begin{array}{l}, 578 \\
(p>0,05)\end{array}$ & $\begin{array}{l}, 011 \\
(p \leq 0,01)\end{array}$ & $\begin{array}{l}, 997 \\
(p>0,05)\end{array}$ & $\begin{array}{l}, 013 \\
(p \leq 0,01)\end{array}$ \\
\hline \multirow{3}{*}{$\begin{array}{lr}\text { II } & \text { период } \\
\text { исследовани } \\
\text { я } \\
2016 г г .\end{array}$} & $\begin{array}{l}\text { Mean норма } \\
(2)\end{array}$ & 17,6 & 19,0 & 13,1 & 10,4 & 14,0 \\
\hline & $\begin{array}{l}\text { Mean } \\
\text { OПН (2) }\end{array}$ & 19,4 & 19,4 & 17,2 & 10,2 & 16,2 \\
\hline & $\begin{array}{l}\text { Asymp. Sig. } \\
\text { (2-tailed) }\end{array}$ & $\begin{array}{l}, 004 \\
(p \leq 0,01)\end{array}$ & $\begin{array}{l}, 351 \\
(p>0,05)\end{array}$ & $\begin{array}{l}0,000 \\
(p \leq 0,01)\end{array}$ & ,868 & 0,009 \\
\hline $\begin{array}{l}\text { Между } \\
\text { группами } \\
\text { ОПН (1) и } \\
\text { ОПН (2) } \\
\end{array}$ & $\begin{array}{l}\text { Asymp. Sig. } \\
\text { (2-tailed) }\end{array}$ & $\begin{array}{l}, 623 \\
(p>0,05)\end{array}$ & $\begin{array}{l}, 992 \\
(p>0,05)\end{array}$ & $\begin{array}{l}0,003 \\
(p \leq 0,01)\end{array}$ & $\begin{array}{l}, 995 \\
(p>0,05)\end{array}$ & $\begin{array}{l}, 669 \\
(p>0,05)\end{array}$ \\
\hline
\end{tabular}

Таблица 2

Значение средних (mean) изначимость различий (Asymp. Sig.) по показателям эмоциональной сферы в группах девушек, подвергшихся насилию (ОПН (1) и ОПН (2), и девушек, не имеющих подобного опыта (норма (1) и норма (2)) за два периода исследования.

Таким образом, у девушек, подвергшихся насилию со стороны своих сверстников, с точки зрения эмоциональной сферы, сильно нарушена адекватность оценки своих действий, выражена боязнь межличностных взаимоотношений (тревожность по поводу их целесообразности и эффективности), суждения об окружающей действительности выносится преимущественно из депрессивной, пессимистической позиции. Однако подобное состояние ими может явно не демонстрироваться (невараженность показателя депрессии-состояния), а в знакомых условиях, конкретно заданной ситуации (например, в школьной действительности), они могут быть даже вполне адекватными и не выказывать признаков повышенной тревожности.

\section{Обсуждение и рекомендации.}

Полученные нами результаты наталкивают на ряд рассуждений, касающихся личностных особенностей девушек, подвергшихся насилию со стороны своих сверстников, и возможных аспектов работы по их психологической реабилитации.

Так, после проведения сравнительного анализа групп девушек, подвергшихся насилию со 
С.Ю. Манухина Исследование особенностей ценностно-смысловой, когнитивной и эмочиональной сфер у девушек подросткового возраста, подвергшихся насилию... стороны сверстников (ОПН(1) и ОПН (2)), и девушек, не имеющих опыта насилия (норма (1) и норма (2)), было выявлено, что девушки групп ОПН (1) и ОПН (2) в целом обладают значимо более низким уровнем представления об общем уровне эффективности своих действий, чем девушки группы «норма». В ряде исследований зарубежных авторов было показано, что чрезмерно низкий уровень представления о собственной эффективности (самоэффективности) отрицательно влияет на мотивацию к достижению результата [МакМаллин, 2001], сказываясь на постановке задач и целей к выполнению деятельности. А.Бандура предположил, что возникновению самоэффективности способствуют четыре основных источника: опыт собственных успехов, наблюдение за чужими достижениями, вербальные убеждения и воспринимаемое эмоциональное и физиологическое состояние [Хьелл, Зиглер, 1997]. Соответственно, если нарушается хотя бы один из этих факторов, изменению подвергается и представление о собственной самоэффективности в целом. Если девушка подверглась насилию, то ее негативный опыт откладывает неизменный отпечаток на ее эмоциональное и физиологическое состояние, на само восприятие, а также на способность и форму восприятия чужих успехов; она их может воспринимать как в негативном свете, так и просто не замечать [Манухина, 2018; Robinson, Smith, Segal, 2018]. Интересным является тот факт, что наряду с низким уровнем общей (личностной) самоэффективности, уровень частной (в данном случае школьной) самоэффективности у таких девушек находится примерно в том же диапазоне, что и у девушек, не подвергавшихся сексуальному насилию. Привычная обстановка, нормативно заданная линия поведения положительно сказывается на восприятии ими собственной эффективности в знакомой деятельности. На наш взгляд, это является хорошим ресурсом для проведения реабилитационной работысдевушками, попавшими в подобную ситуацию. Линию психологической работы с ними можно выстраивать, основываясь на резервных сферах жизни, где они чувствуют себя надежными, эффективными в деятельности. Вероятно, возможно найти и другие знакомые для них по прошлому опыту, привычные в обыденной жизни сферы жизни и стереотипы поведения.

В исследовании, проведенном Ф. Паджересом и А. Джонсоном [Pajares, 1996], были получены данные, свидетельствующие о том, что общая (личная) самоэффективность, хотя и связана с частной (например, самоэффективностью школьной деятельности) самоэффективностью, но в отличие от последней никак не связана с уровнем успешности в конкретной деятельности. Это же подтверждается и результатами нашего исследования. Дополнительный анализ выборки испытуемых показал, что существенных изменений по уровню школьной (академической) успеваемости между девушками групп норма (норма (1) и норма (2)) и ОПН (ОПН (1) и ОПН (2)) продемонстрировано не было, что указывает на то, что опыт насильственных действий, полученный ими, в отношении успеха в конкретной знакомой деятельности (в данном случае школьной) особого влияния не оказал. Однако подверглось изменению само восприятие своих интеллектуальных возможностей. Так, результаты нашего исследования показали, что если вера в рольусилий удевушек группы норма(1) и групп ОПН (1) значимо не отличаются, то уже между группами норма (2) и ОПН (2) у современных подростков мы можем наблюдать значимые различия по данным показателям. В то же время вера в роль собственных способностей у девушек, подвергшихся насилию и в первый, и во второй периоды исследования, значимо занижена в сравнении с девушками, не имеющих опыта насилия. В исследовании, проведенном Клаудией Мюллер и Кэрол Двек [Dweck, 1999], было показано, что испытуемые, которые считают, что их способности изменяемы, поддаются улучшению и тренировке, склонны ставить перед собой задачи, направленные на достижение результата, учебные и познавательные цели (learning goals), то есть они стремятся увеличить свою компетентность и мастерство. Соответственно, они предпочитают новые, трудные и разнообразные задачи, которые могут им помочь чему-то научиться, продвинуться в своем развитии. У девушек, подвергшихся насильственным действиям, по-видимому, подверглась изменению сама сфера целеполагания. Основываясь на своем прошлом опыте, они верят, что, если приложат усилие к выполнению каких-либо действий (группа ОПН (1)) или проявят властность (группа ОПН(2)), то достигнут результата, но вот желание к проявлению активности, к постановке и реализации задач, 


\section{S.Yu. Manukhina The research of the values, the cognitive and emotional indicators}

of adolesent girls who were exposed to violence by the peers

к развитию и самосовершенстованию у них, видимо, весьма снижено. Это же подтверждают и результаты, полученные при исследовании у этих девушек особенностей ценностно-смысловой сферы. В их группе на первое место вышли такие ценности как здоровье (физическое и психическое), ответственность, преданность, честность, умеренность, смирение, группа (ОПН1) и в группе ОПН (2) дополнительно - влиятельность. Последнее же место в списке заняли снисходительность, доброжелательность, самостоятельность, целеустремленность. Такая амбивалентность ценностных представлений - образ собственной чистоты, правильности, психической и физической безопасности, с одной стороны, и настороженное и даже где-то агрессивное настроение по отношению к окружающим, с другой, - указывает на их шаткую, неустойчивую позицию самовосприятия себя в окружающем мире, чрезмерной их личностной ранимости. Разделение мира на «белые» и «черные» стороны, на «наши» и «не наши» взгляды опасно для дальнейшего личностного развития этих девушек. «Так, для женщин, подвергшихся насилию, все люди стали делиться на насильников - мужчин и жертв - женщин» [Черепанова, 1996, с. 32]. И их путь будет зависеть от того, какую «строну баррикад» они выберут. По ряду статистических исследований было показано, что для женщины, принявшей позицию «жертвы», вероятность подвергнуться повторному насилию достаточно велика [Гордеев, Гордеева, 1996; Писклакова-Паркер, Синельнико и др., 2010]. То же самое, по-видимому, происходит и с девушками, подвергшимся насилию со стороны сверстников. Они как бы провоцируют своим поведением к насилию. Также велика вероятность и того, что эти девушки могут «пойти по линии» антисоциального поведения: приобщиться к наркотикам, «скверным компаниям». «... если у кого-то из молодых людей есть проблемы с алкоголем, наркотиками, они становятся проститутками или у них суицидальные идеи, то первая гипотеза взрослых должна касаться вероятных эпизодов насилия, которые они пережили в детстве,» - отмечает Черепанова Е. [Черепанова, 1996, с. 71]. Отнесение ценностей, связанных с целеполаганием, девушками групп ОПН (1) и ОПН (2) на последние места характеризует их как людей, живущих сегодняшним днем и не заботящихся о дне завтрашнем, не проявляющих настойчивости и активности. Их паттерн поведения похож на пессимистический стиль поведения, описанный М. Зелигманом [Зелигман, 1997]. При пессимистическом стиле объяснения неудачи, неблагоприятные события воспринимаются субъектом как связанные с личными (внутренними) характеристиками, являющимися постоянными, глобальными; а успех (хорошие события) рассматривается как временный, относящийся к конкретной области и вызванный внешними причинами. В сравнении с этим, при оптимистическом стиле объяснение успехов или неудач осуществляется в противоположном направлении, чем при пессимистическом: неудача воспринимается как временная, конкретная, вызванная внешними факторами, успех - как нечто постоянное, глобальное, вызванное личностными причинами. По-видимому, объяснение причин успеха и неудач в пессимистическом свете присуще при большинстве травматических явлений, отражающихся на самовосприятии личности. В ряде исследований было показано, что беспомощный, пессимистический объяснительный стиль является предиктором депрессии, а оптимистический - психического и физического здоровья. В наших предыдущих исследованиях было показано наличие значимой связи между проявлением настойчивости испытуемых и их склонности к депрессивным тенденциям. Оказалось, что более настойчивые менее склонны к проявлению депрессивных черт, чем менее настойчивые [Манухина, 2003]. В настоящем же исследовании было показано, что девушки, пережившие опыт насилия, обладают значимо более выраженными депрессивными чертами, чем девушки, не имеющие подобного опыта. Это хорошо и логично объясняет их ощущения ирреальности окружающего мира и низкой самоэффективности в нем. Соответственно, еще одна линия работы психолога по реабилитации девушек групп ОПН должна касаться преодоления их депрессивного, пессимистического настроя с возможным нахождением оптимистических стратегий объяснения текущих событий.

Еще одной сферой, по-видимому, вызывающей сильную тревогуу девушек групп ОПН, является сфера межличностных отношений. Так, нами было показано, что у девушек, подвергшихся 
С.Ю. Манухина Исследование особенностей иченностно-смысловой, когнитивной и эмочиональной сфер у девушек подросткового возраста, подвергшихся насилию...

насилию со стороны своих сверстников, уровень межличностной тревожности значимо выше, чем у девушек, не имеющих подобного опыта. При высоком уровне межличностной тревожности поведение может выстраиваться преимущественно в двух ключах: либо человек «замыкается в себе», опасаясь и прерывая большинство межличностных контактов, либо, наоборот, его поведение становится демонстративным, носящим большое количество поверхностных контактов. Рядом авторов (Черепанова Е., 1996; Ткаченко А.А., Дворянчиков Н.В., Ковальчук Ю., 200о; Пушкарев А.Л., Доморацкий В.А., Гордеева Е.Г., 2000, Манухина Н.М., 2018 и др.) отмечается, что у травмированных личностей при проявлении посттравматических стрессовых реакций наблюдается смена базовых иллюзий: разрушение одних и построение других. В частности, страдает и сфера межличностных отношений. Так, инцестное поведение сильно сопряжено с четкой иерархией в «инцестной семье», и на основе этого присвается конкретная роль в паттерне [Ткаченко, Дворянчиков, Ковальчук, 200о]. В подростковой среде в силу возрастных особенностей групповые ценности стоят выше индивидуальных. Их групповые взаимоотношения также сильно иерхатизированы. Опасность при межличностных взаимоотношениях со своими сверстниками для девушек, подвергшихся насилию со стороны сверстников, заключается в неадекватном построении линии поведения с ними. Ни к чему хорошему не ведет как страх и нежелание общаться, так и чрезмерная готовность к контактам. Первое может вести к озлобленности, агрессивности и, в некоторых случаях, инфантилизации личности. Второе - к повторному насилию, возможной распущенности, получению очередной психологической травмы.

Хорошим эмоциональным ресурсом для них является, как мы отмечали ранее, погружение в хорошо знакомую деятельность с давно выработанным стереотипом поведения, желательно подкрепленным доброжелательной обстановкой. Так, нами было показано, что уровень школьной тревожности находится в том же диапазоне, что и у девушек групп норма. Этот результат указывает на то, что сама форма знакомой деятельности опасений и эмоционального напряжения у девушек групп ОПН не вызывает, а скорей, наоборот, способствует их «вхождению» в нормальный ритм жизни. Соответственно, при работе с такими девушками желательно опираться на ту сферу их жизни, которая у них не вызывает тревоги, постепенно расширяя ракурс ее влияния.

\section{ЛИТЕРАТУРА}

1. Гордеев М.Н., Гордеева Е.Г., Колошина Т.Ю. Психотерапевтическая работа с женщинами, подвергшимися сексуальному насилию. Современные направления психотерапии и их клиническое применение: Материал первой Всероссийской учебно-практической конференции по психотерапии. - Москва, 1996.

2. Здоровые и безопасные отношения: предовращение насилия при свиданиях подростков. Пособие для учителей. Тарту, 2016.

3. Зелигман М. Как научиться оптимизму. - Москва: Вече, Персей, 1997.

4. Карелин А. Большая энциклопедия психологических тестов. - Москва: Эксмо, 2007.

5. Литтл Т.Д., Ваннер Б., Гордеева Т.О. Мульти-КАМ: о школе и школьной жизни. Версия 3.о R. Йельский Университет (США) и Институт развития человека им. Макса Планка (Берлин, Германия), 1998.

6. МакМаллин Р. Практикум по когнитивной терапии. - Санкт-Петербург: Речь, 2001.

7. Манухина Н.M. Насилие в семье, 2018 http://psyholog.biz/publikatsii/stati/nasilie-v-seme

8. Манухина Н.М., Манухина С.Ю. и др. Психолог в организации. - Москва: Класс, 2015.

9. Манухина С.Ю. Эмпирический анализ мотивации достижения как структурного образования.// Вестник МгУ. Сер.14. 2003. № 1 .

10. МКБ-10: Классификация психических и поведенческих расстройств: исследовательские диагностические критерии. Санкт-Петербург, 1994

11. Официальная статистика Федеральной службы государственной статистики числа несовершеннолетних, совершивших преступление в период с 1990 по 2015 гг. http://cbsd.gks.ru/ 


\section{S.Yu. Manukhina The research of the values, the cognitive and emotional indicators}

of adolesent girls who were exposed to violence by the peers

12. Писклакова-Паркер М., Синельников А. и др. Насилие в отношении женщин в России., 2010 http://www.cdep.ru/mps/4/ch4/Alter\%202.pdf

13. Прихожан A.M. Тревожность у детей и подростков: психологичексая природа и возрастная динамика. - Москва: Московский психолого-социальный институт, - Воронеж: НПО « МОДЭК», 2000.

14. Тихомандрицкая O.A., Дубовская E.M. Особенности социально-психологического изучения ценностей как элементов когнитивной и мотивационно-потребностной сферы // Мир психологии. 1999. № 3. С. 80-90.

15. Ткаченко А.А., Дворянчиков Н.В., Ковальчук Ю. Механизмы инцестного поведения // Российский психиатрический журнал. 2000. №1. С.6-13.

16. Тухарев А. Школьный психолог наших дней // Газета «Первое сентября». - Москва, 2001.

17. Хъелл Л., Зиглер Д. Теории личности. - Санкт-Петербург: Питер, 1997.

18. Черепанова Е. Психологический стресс. Помоги себе и ребенку. - Москва: Academia, 1996, C.32.

19. Шварцер Р., Ерусалем М., Ромек В. Русская версия шкалы общей самоэффективности Р. Шварцера, М. Ерусалема // Иностранная психология. 1996. №6. С.47-58.

20. Bandura A. Self-efficacy. The exercise of control. Freeman and Co., New York, 1997.

21. Deci E.L., Ryan R.M. Intrinsic motivation and self-determination in human behavior. New York: Plenum, 1985.

22. Dweck C.S. Capturing the dynamic nature of personality.// Journal of research in Personality. 1996.Vol. 30. PP.348-362..

23. Dweck C.S. Self-theories: Their role in motivation, personality, and development. - Philadelphia: Psychology Press, Taylor \& Francis Group, 1999.

24. Gomez-Baya1 D., Mendoza R., Paino S. Revista Emotional basis of gender differences in adolescent self-esteem// Psicologia. 2016, Vol. 30 (2). P. 1-14.

25. Gordeeva T.O., Manuchina S., Shatalova Ju. Cognitive and emotional predictors of academic achievement motivation.// Paper to be presented at the $8^{\text {th }}$ International Conference on Achievement and Task Motivation. Moscow, June 12-15, 2002.

26. Kumari A., Sandhya G. A study of emotional intelligence and frustration tolerance among adolescent.// Advance research journal of social science. 2015 Vol.6.

27. Little T.D., Wanner B. The multi-CAM: A multidimensional instrument to assess children's action-control motives, beliefs, and behaviors. Max-Planck - Institut fur Bildungsforschung. Berlin, 1997.

28. Pajares F. Self-efficacy beliefs in Academic Settings // Review of Educational Research, 1996. 66 (4). P. 543-578.

29. Robinson L., Smith M., Segal J. Emotional and Psychologycal Trauma. 2018 https://www.helpguide.org/

\section{REFERENCES}

1. Bandura A. Self-efficacy. The exercise of control. Freeman and Co., New York, 1997.

2. Cherepanova E. Psihologicheskij stress. Pomogi sebe i rebenku [Psychological stress. Help yourself and the baby]. Moscow, Academia, 1996.

3. Deci E.L., Ryan R.M. Intrinsic motivation and self-determination in human behavior. New York: Plenum, 1985

4. Dweck C.S. Capturing the dynamic nature of personality. In Journal of research in Personality. 1996.Vol. 30. PP.348-362.

5. Dweck C.S. Self-theories: Their role in motivation, personality, and development. Philadelphia, Psychology Press, Taylor \& Francis Group, 1999.

6. Gomez-Baya1 D., Mendoza R., Paino S. Revista Emotional basis of gender differences in adolescent self-esteem. In Psicologia. 2016, Vol. 30 (2). Pp. 1-14.

7. Gordeev M.N., Gordeeva E.G., Koloshina T.Yu. Psihoterapevticheskaja rabota s zhenshhinami, podvergshimisja seksual'nomu nasiliju. Sovremennye napravlenija psihoterapii $i$ ih klinicheskoe primenenie: Materialv pervoj Vserossijskoj uchebnoprakticheskoj konferencii po psihoterapii [Psychotherapeutic work with women who have been sexually abused. Modern directions of psychotherapy and their clinical application: Material of the first All-Russian educational and practical conference on psychotherapy]. Moscow, 1996.

8. Gordeeva T.O., Manuchina S., Shatalova Ju. Cognitive and emotional predictors of academic achievement motivation. In Paper to be presented at the 8th International Conference on Achievement and Task Motivation. Moscow, June 12-15, 2002. 9. Hjell L., Ziegler D. Teorii lichnosti [Theories of personality]. Saint-Petersburg, Peter, 1997.

10. Karelin A. Bol'shaja jenciklopedija psihologicheskih testov [A large encyclopedia of psychological tests]. Moscow, Eksmo, 2007.

11. Kumari A., Sandhya G. A study of emotional intelligence and frustration tolerance among adolescent. In Advance research journal of social science. 2015, Vol.6. 
С.Ю. Манухина Исследование особенностей иченностно-смысловой, когнитивной и эмочиональной сфер у девушек подросткового возраста, подвергшихся насилию...

12. Little T.D., Wanner B. The multi-CAM: A multidimensional instrument to assess children's action-control motives, beliefs, and behaviors. Max-Planck - Institut fur Bildungsforschung. Berlin, 1997.

13. Little T.D., Vanner B., Gordeeva T.O. Mul'ti-KAM: o shkole i shkol'noj zhizni. Versija 3.o R. Jel'skij Universitet (SShA) $i$ Institut razvitija cheloveka im. Maksa Planka (Berlin, Germanija) [Multi-KAM: about school and school life. Version 3.o R. Yale University (USA) and the Institute of Human Development. Max Planck (Berlin, Germany)], 1998.

14. Manukhina N.M. Nasilie $v$ sem'e [Domestic Violence], 2018. URL: http://psyholog.biz/publikatsii/stati/nasilie-v-seme 15. Manukhina N.M., Manukhina S.Yu. Psiholog v organizacii [Psychologist in the organization]. Moscow, Class, 2015.

16. Manukhina S.Yu. Jempiricheskij analiz motivacii dostizhenija kak strukturnogo obrazovanija [An empirical analysis of the motivation of achievement as a structural formation]. In Bulletin of the Moscow State University. Ser.14. 2003. № 1.

17. McMullin R. Praktikum po kognitivnoj terapii [Workshop on cognitive therapy]. Saint-Petersburg, Speech, 2001.

18. MKB-10: Klassifikacija psihicheskih i povedencheskih rasstrojstv: issledovatel'skie diagnosticheskie kriterii [Classification of mental and behavioral disorders: research diagnostic criteria]. Saint-Petersburg, 1994

19. Oficial'naja statistika Federal'noj sluzhby gosudarstvennoj statistiki chisla nesovershennoletnih, sovershivshih prestuplenie $v$ period s 1990 po $2015 \mathrm{gg}$. [Official statistics of the Federal State Statistics Service of the number of minors who committed a crime between 1990 and 2015]. URL: http://cbsd.gks.ru/

20. Pajares F. Self-efficacy beliefs in Academic Settings. In Review of Educational Research, 1996. 66 (4). Pp. 543-578.

21. Pisklakova-Parker M., Sinelnikov A. et al. Nasilie $v$ otnoshenii zhenshhin $v$ Rossii [Violence against women in Russia], 2010. URL: http://www.cdep.ru/mps/4/ch4/Alter\%202.pdf

22. Prikhozhan A.M. Trevozhnost' $u$ detej i podrostkov: psihologicheksaja priroda i vozrastnaja dinamika [Anxiety in children and adolescents: psycho-social nature and age dynamics]. Moscow, Moscow Psychological and Social Institute; Voronezh, NGO "MODEK", 2000

23. Robinson L., Smith M., Segal J. Emotional and Psychologycal Trauma. 2018. URL: https://www.helpguide.org/ 24. Schwarzer R., Erusalem M., Romek V. Russkaja versija shkaly obshhej samojeffektivnosti R. Shvarcera, M. Erusalema [Russian version of the scale of general self-efficacy R. Schwarzer, M. Erusalem]. In Inostrannaja psihologija [Foreign psychology]. 1996. № 6. Pp. 47-58.

25. Tikhomandritskaya O., Dubovskaya E. Osobennosti social'no-psihologicheskogo izuchenija cennostej kakjelementov kognitivnoj i motivacionno-potrebnostnoj sfery [Peculiarities of socio-psychological study of values as elements of cognitive and motivationalneed sphere]. In Mir psihologii [The world of psychology]. 1999. No. 3. Pp. 80-90.

26. Tkachenko A.A., Dvoryanchikov N.V., Kovalchuk Yu. Mehanizmy incestnogo povedenija [Mechanisms of incest behavior]. In Rossijjskij psihiatricheskij zhurnal [Russian psychiatric journal]. 2000. № 1. Pp. 6-13.

27. Tukharev A. Shkol'nyh psiholog nashih dnej [School psychologist of our days]. In Gazeta "Pervoe sentjabrja" [The First of September Newspaper]. Moscow, 2001.

28. Zdorovye i bezopasnye otnoshenija: predovrashhenie nasilija pri svidanijah podrostkov. Posobie dlja uchitelej [Healthy and safe relationships: preventing violence during adolescent visits. A handbook for teachers]. Tartu, 2016.

29. Zeligman M. Kak nauchit'sja optimizmu [How to learn optimism]. Moscow, Veche, Perseus, 1997. 